ISSN: 1410-8917

Jurnal Kimia

Sains \&

Aplikasi

e-ISSN: 2597-9914
Jurnal Kimia Sains dan Aplikasi Journal of Scientific and Applied Chemistry

Journal homepage: http://ejournal.undip.ac.id/index.php/ksa

\title{
Characterization and Application of Chitosan as a Natural Coagulant in Reducing Remazol Red Dyestuff Concentration and COD Value of Batik Liquid Waste
}

\author{
Rifana Adilla Safitri ${ }^{\mathrm{a}, 1}$, Maya Rahmayanti ${ }^{\mathrm{a}, 2,{ }^{*}}$ \\ ${ }^{a}$ Department of Chemistry, Faculty of Science and Technology, Universitas Islam Negeri Sunan Kalijaga, Yogyakarta, Indonesia \\ * Corresponding author: (1) rifanaadillasafitri@gmail.com; $(2, *)$ maya.rahmayanti@uin-suka.ac.id
}

https://doi.org/10.14710/jksa.23.9.333-337

\section{Article Info}

Article history:

Received: $18^{\text {th }}$ July 2020

Revised: $11^{\text {th }}$ September 2020

Accepted: $20^{\text {th }}$ September 2020

Online: $30^{\text {th }}$ September 2020

Keywords:

coagulation; chitosan; remazol red

\begin{abstract}
Research on chitosan application as a natural coagulant in reducing the concentration of remazol red dye from batik liquid waste has been carried out. This study aims to study the effect of the acidity of batik wastewater on the coagulant ability to reduce the remazol red dye concentration and the COD value of batik liquid waste. In this study, chitosan compounds before and after coagulation were characterized using Fourier Transform Infrared (FTIR) Spectroscopy. The $\mathrm{pH}$ range used in the coagulation process was $\mathrm{pH} 2-6$. Postcoagulation chitosan FTIR spectra showed a shift in the wave number in the 3400 $\mathrm{cm}^{-1}$ area, which indicated an interaction between the $-\mathrm{OH}$ group of chitosan and the dye remazol red. Remazol red dye was maximally coagulated by chitosan at $\mathrm{pH}$ 2. The percentage reduction in the dye concentration reached $100 \%$, and the decrease in COD value at that $\mathrm{pH}$ was $71.69 \%$.
\end{abstract}

\section{Introduction}

The development of the batik industry has had some positive and negative impacts. The negative impacts include the emergence of environmental problems due to batik liquid waste containing synthetic dye residue. The use of synthetic dyes such as remazol, naphthol, and indigosol produces synthetic dye waste that is nonbiodegradable, carcinogenic, and can cause liver, kidney, anemia, and other cell disorders [1]. The treatment of dye waste before disposal needs to be done to avoid the risk of these hazards. Several researchers have reported using the adsorption method to reduce the dye contained in batik wastewater $[2,3,4,5,6,7]$. Based on this research, the use of the adsorption method could not reduce the dye concentration in batik waste optimally.

In this study, the remazol red concentration in batik wastewater was reduced using the chitosan coagulation method. Remazol red dye is one type of dye that is often used by the batik industry in Yogyakarta. Remazol red dye is widely used because it has a reasonably strong color resistance. However, its photodegradation process in nature is prolonged [8], so it is necessary to find an appropriate and straightforward method to reduce the concentration of remazol red dye in batik liquid waste.

Coagulation is treating waste by adding a coagulant to the waste by stirring rapidly so that a homogeneous waste dispersion is obtained. Coagulation occurs due to the ions originating from the coagulant, which have a charge opposite the colloidal particles' charge. The addition of a coagulant causes instability of the colloid particles and binds the colloid particles to form a floc. Coagulants can neutralize the charge of colloidal particles and bind these colloidal particles to form floc [9]. The use of coagulants from synthetic chemicals can cause new problems in the environment due to synthetic byproducts. Therefore, it is necessary to look for alternative coagulants from natural materials that tend to be environmentally friendly and effective in reducing the dye content in batik wastewater.

Chitosan is poly-2-amino-2-deoxy- $\beta-1,4-D-$ glucopyranose with the molecular formula C6H11NO6 obtained from the chitin distillation process. Chitin comes from the skin, head, and tail of shrimp, which can be obtained from waste of vanamei shrimp, crab waste, and silage from tiger prawn heads [10]. Chitosan has a 
good role in reducing environmental pollution, which is quite effective in purifying water and wastewater. Chitosan can reduce color levels, pH, BOD, COD, and can absorb heavy metals and dyes [10, 11]. Based on the properties and advantages of chitosan, in this study, chitosan was applied as a natural coagulant to reduce the dye concentration of remazol red and the COD value of batik liquid waste. As far as the author's knowledge, chitosan has never been used to process batik liquid waste dye. The effect of the acidity of the batik wastewater on the coagulant ability to reduce the remazol red dye concentration and the COD value of batik wastewater was studied in the $\mathrm{pH}$ range 2-6.

\section{Methodology}

\subsection{Equipment and Materials}

The equipment used in this study were: a set of standard laboratory glassware, Whatman 42 filter paper, universal pH, tweezers, analytical balance, teaspoon and glass stirrer, hotplate centrifuge, Shimadzu-8201 PC Fourier Transform Spectrophotometer (FTIR), and Spectrophotometer. UV-Vis 1800 Double Beam Shimadzu.

The primary materials used in this study include ready-to-use chitosan from the isolation of shrimp or crab shells produced by CV Chimultiguna (the structure of the chitosan compound is presented in Figure 1), batik liquid waste, and a standard solution of remazol red dye specifically for batik dyes (the structure of the remazol red compound is presented in Figure 2).

Meanwhile, this study's supporting materials included $\mathrm{HCl}, \mathrm{NaOH}$, and distilled water, all of which were of analytical quality obtained from Merck.

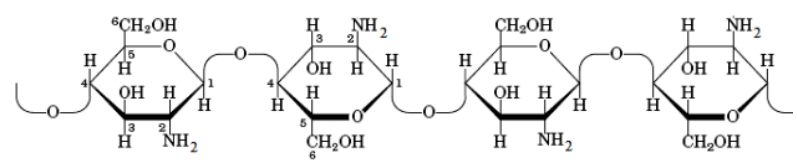

Figure 1. Structure of chitosan<smiles>COc1ccc(S(=O)(=O)OCCOS(=O)(=O)O)cc1N=Nc1ccc2c(S(=O)(=O)O)cccc2c1O</smiles>

Figure 2. Structure of remazol red dye

\subsection{Material characterization}

The coagulant chitosan and standard remazol red dye used in this study were characterized by functional groups using an FTIR spectrophotometer.

\subsection{Preparation of batik liquid waste solution at various pHs}

Batik liquid waste (30 mL each) was poured into a $100 \mathrm{~mL}$ beaker, and the $\mathrm{pH}$ is adjusted to the range 2-6. The $\mathrm{pH}$ adjustment was made by adding a solution of $\mathrm{HCl}$ and/or $\mathrm{NaOH}$. The initial content of remazol red dye in batik liquid waste of various $\mathrm{pH}$ was analyzed using a UV-Vis Spectrophotometer. The initial and final COD values of batik liquid waste were tested at the Testing and Calibration Laboratory, Center for Environmental Health and Disease Control Engineering (BBTKLPP), Yogyakarta.

\subsection{Remazol red standard solution preparation}

\subsubsection{Preparation of remazol red mother liquor}

The main solution of $1000 \mathrm{ppm}$ remazol red dye was prepared by dissolving $1 \mathrm{~g}$ of remazol red in $1000 \mathrm{~mL}$ of distilled water. Next, the mother liquor was diluted into $5,10,15,20$, and $25 \mathrm{ppm}$ of $30 \mathrm{~mL}$ each, which was then used as standard solutions.

\subsubsection{Determination of the maximum wavelength of the remazol red dye}

The maximum wavelength was determined by measuring the remazol red solution in the wavelength range of 400-750 $\mathrm{nm}$ using a UV-Vis spectrophotometer. The maximum wavelength obtained was then used for the measurement of the standard solution.

\subsubsection{Determination of the standard curve of the dye remazol red}

The mother liquors of remazol red dye with variations of $5,10,15,20$, and $25 \mathrm{ppm}$ were measured their absorbance using a UV-Vis spectrophotometer at the maximum wavelength of remazol red. Furthermore, a graph of the relationship between concentration and absorbance of remazol red dye solution was made as a calibration curve

\subsection{Coagulation of batik wastewater using chitosan as a coagulant}

$0.300 \mathrm{~g}$ of chitosan were each put into a $100 \mathrm{~mL}$ beaker and mixed with $30 \mathrm{~mL}$ of batik liquid waste solution with $\mathrm{pH}$ variations of $2,3,4,5$, and 6 . The mixture was stirred for 60 minutes with a variety of stirring, where the first 3 minutes of stirring was done quickly, and the next 30 minutes was done with slow stirring. Then, the mixture was left for 30 minutes. Then the mixture was filtered using Whatman filter paper. The dye concentrations of each filtrate were analyzed using a UV-Vis spectrophotometer with three repetitions followed by COD testing. Meanwhile, the precipitate obtained was dried and then characterized using an FTIR spectrophotometer.

\subsection{Testing the COD (Chemical Oxygen Demand) value}

COD testing is carried out by sending the coagulated filtrate to the Testing and Calibration Laboratory, Center for Environmental Health and Disease Control Engineering (BBTKLPP), Yogyakarta.

\section{Results and Discussion}

\subsection{FTIR spectra of chitosan}

Chitosan characterization was performed using an FTIR spectrophotometer. This characterization was carried out on chitosan before the coagulation process 
and chitosan after coagulation. The purpose of characterization was to determine the functional groups in chitosan and determine changes in the functional groups in chitosan before and after coagulation. The FTIR analysis spectra of chitosan before and after coagulation are presented in Figure 3.

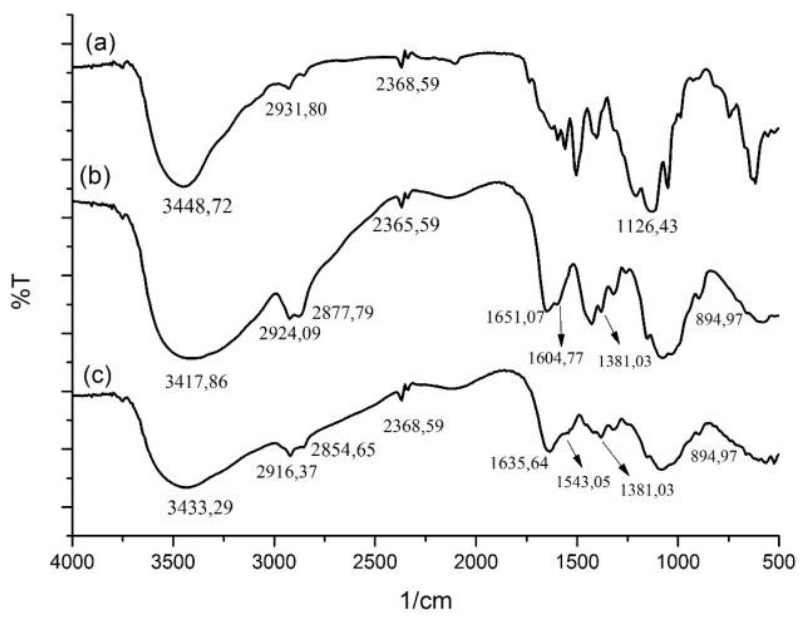

Figure 3. FTIR spectra of (a) remazol red dye, (b) chitosan before coagulation, (c) chitosan after coagulation

Table 1. Wave numbers on chitosan FTIR spectra, before and after coagulation

\begin{tabular}{cccc}
\hline No & Functional groups & \multicolumn{2}{c}{ wavenumber $\left(\mathrm{cm}^{-1}\right)$} \\
\cline { 3 - 4 } & & $\begin{array}{c}\text { before } \\
\text { coagulation }\end{array}$ & $\begin{array}{c}\text { after } \\
\text { coagulation }\end{array}$ \\
\hline 1 & (vb) O-H which overlaps with & 3417.86 & 3433.29 \\
& (vs) N-H & & \\
2 & (vb) aliphatic C-H & 2924.09 & 2916.37 \\
3 & (vs) Aliphatic C-H & 2877.79 & 2854.65 \\
4 & (vs) aromatic C-H & 2368.59 & 2368.59 \\
5 & (v) C=O [secondary amide] & 1694.77 & 1635.64 \\
6 & (v) C=O [secondary amide & 1604.77 & 1543.05 \\
& protonation] & & \\
7 & $\quad \omega$ CH & 1381.03 & 1381.03 \\
8 & $\omega \beta-1,4$-glycosidic & 894.97 & 894.97 \\
\hline
\end{tabular}

Note: v: stretching vibration, vs: symmetrical stretching vibration, vb: bending vibration, $\omega$ : stretching vibration

Figure 3 (b) shows that the chitosan spectra before coagulation had several main peaks at wavenumber $894.97 \mathrm{~cm}^{-1} ; 1381.03 \mathrm{~cm}^{-1} ; 1604.77 \mathrm{~cm}^{-1} ; 1651.07 \mathrm{~cm}^{-1}$; $2368,59 \mathrm{~cm}^{-1} ; 2877.79 \mathrm{~cm}^{-1} ; 2924.09 \mathrm{~cm}^{-1}$; and 3417.86 $\mathrm{cm}^{-1}$. The characteristic of chitosan can be seen by the appearance of stretching vibrations in the area of wave number $894.97 \mathrm{~cm}^{-1}$, which indicates the presence of $\beta-$ 1,4-glycosidic bonds. The emergence of absorption at the wave number $1694.77 \mathrm{~cm}^{-1}$ indicates a stretching vibration of the $\mathrm{N}-\mathrm{H}$ group from the amide [12]. The appearance of absorption at wave number $1694.77 \mathrm{~cm}^{-1}$ indicates a stretching vibration of the amide's $\mathrm{N}-\mathrm{H}$ group. Meanwhile, Figure 3 (c) shows that the chitosan spectra after coagulation did not give rise to new absorption but several shifts in the wave number in the wavenumber $3400 \mathrm{~cm}^{-1}$, as shown in Table 1 . It is suspected that the interaction that occurs between chitosan and remazol red is merely a physical interaction. The absorption peak shift is thought to be due to the electrostatic interaction between chitosan and remazol red dye, described in more detail in section 3.2.

\subsection{The effect of $\mathbf{p H}$ variation of batik wastewater on the ability of chitosan coagulant to reduce the concentration of remazol red}

Many factors influence the coagulation process, one of which is $\mathrm{pH}$. The $\mathrm{pH}$ variation of batik wastewater was carried out to determine the optimum $\mathrm{pH}$ conditions for the coagulation of remazol red dye using chitosan coagulant. The variation in $\mathrm{pH}$ in the coagulation process can determine the interaction model between the coagulant and the dye remazol red.

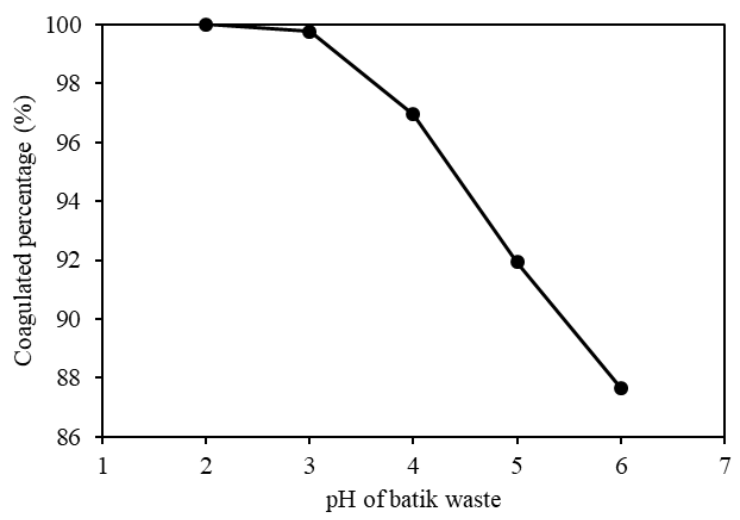

Figure 4. The relationship between $\mathrm{pH}$ and the percentage of coagulated remazol red (\%)

Figure 4 shows that the chitosan coagulant's ability to coagulate remazol red dye decreases with increasing $\mathrm{pH}$. The highest coagulation $\mathrm{pH}$ was obtained at $\mathrm{pH} 2$. This can be explained that chitosan is a compound that is rich in $-\mathrm{NH}_{2}$ and $-\mathrm{OH}$ groups. In the acidic conditions, the functional groups undergo protonation of $-\mathrm{NH}_{3}{ }^{+}$and $-\mathrm{OH}_{2}{ }^{+}$so that the chitosan surface becomes positive [2, 13, 14]. Meanwhile, remazol red is an anionic dye which contains a sulfonic acid group $\left(\mathrm{RSO}_{3}{ }^{-}\right)$. Under acidic conditions, the sulfonic groups of the remazol red are negatively charged, and with increasing $\mathrm{pH}$, the charge becomes neutral [15]. This causes the coagulation process to run well at $\mathrm{pH} \mathrm{2-3,} \mathrm{due} \mathrm{to} \mathrm{the} \mathrm{interaction}$ between the coagulant and remazol red dye, which is suspected through electrostatic interactions. As the $\mathrm{pH}$ increases, $\mathrm{H}^{+}$ions decrease so that the $-\mathrm{NH}_{2}$ and $-\mathrm{OH}$ groups in the chitosan are not properly protonated. The interaction between coagulant chitosan and remazol red is getting weaker at $\mathrm{pH}>3$. This is because at $\mathrm{pH}>3$, the $-\mathrm{NH}_{2}$ and $-\mathrm{OH}$ groups have begun to deprotonate into $\mathrm{NH}-$ and -O- so that the surface becomes negative and makes electrostatic interactions more difficult to occur. This coagulation strengthens the chitosan FTIR spectra results before and after coagulation, which does not produce new absorption. It only shows a shift in the wave number in the $3400 \mathrm{~cm}^{-1}$ absorption area, which is the $\mathrm{O}-\mathrm{H}$ absorption of the $\mathrm{N}-\mathrm{H}$ overlap. This shows that the interaction between chitosan coagulant and remazol red dye is through electrostatic interaction. An illustration of the interaction between chitosan and RR dye is presented in Figure 5. 


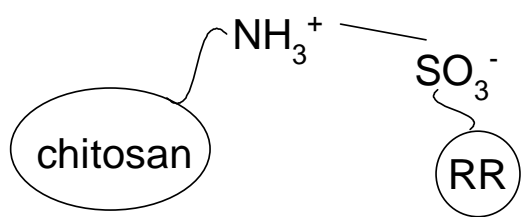

Figure 5. Illustration of the interaction between chitosan and remazol red

\subsection{The performance of chitosan coagulant in reducing COD value of batik liquid waste}

One of the parameters of wastewater quality that is often tested is the COD (Chemical Oxygen Demand) value. Chemical Oxygen Demand is the amount of oxygen required to oxidize compounds present in the water through a chemical reaction. Organic compounds are oxidized by potassium bichromate to $\mathrm{CO}_{2}$ and $\mathrm{H}_{2} \mathrm{O}$ gases and chromium ions. The higher the COD value in a sample of wastewater, the lower the quality and vice versa. Organic compounds in batik liquid waste other than dyes are waxes, so the concentration needs to be lowered before being discharged into the environment. Based on Table 2, the percentage reduction in COD value in this study was $71.69 \%$. This value is lower than the chitosan coagulant's ability to reduce the concentration of the remazol red. This is presumably because chitosan coagulant has not interacted strongly with other organic compounds in the batik liquid waste. So, it is necessary to find the optimum conditions that are more appropriate to treat other organic compounds in the batik liquid waste other than remazol red.

Table 2. COD value of batik liquid waste at $\mathrm{pH} 2$ conditions

\begin{tabular}{lccc}
\hline & $\begin{array}{c}\text { before } \\
\text { coagulation } \\
(\mathrm{mg} / \mathrm{L})\end{array}$ & $\begin{array}{c}\text { After coagulation } \\
(\mathrm{mg} / \mathrm{L})\end{array}$ & $\begin{array}{c}\% \\
\text { reduction }\end{array}$ \\
\hline $\mathrm{COD}$ & 1189.58 & 358.99 & 71.69 \\
\hline
\end{tabular}

Table 3. The performance of chitosan coagulant in reducing COD value of several types of waste

\begin{tabular}{ccc}
\hline Types of waste & $\begin{array}{c}\text { the percentage } \\
\text { reduction in COD } \\
\text { value }\end{array}$ & Information \\
\hline $\begin{array}{c}\text { drainage water in the } \\
\text { Singosari sewer in } \\
\begin{array}{c}\text { Semarang } \\
\text { laundry liquid waste }\end{array}\end{array}$ & 75.63 & {$[11]$} \\
Batik liquid waste & 72.67 & {$[6]$} \\
& 71.69 & $\begin{array}{c}\text { This } \\
\text { research }\end{array}$ \\
\hline
\end{tabular}

Many studies have been reported related to waste treatment by coagulation methods using chitosan. This method is quite good at reducing COD values in various types of waste. The performance of chitosan coagulant in reducing COD values for several types of waste is presented in Table 3. Based on Table 3, it can be seen that the coagulation method using chitosan is an effective method to be applied to various types of waste. The coagulation method in the waste treatment process involves forming clots or flocks originating from colloidal particles in liquid waste, which is subject to particle destabilization due to stirring variations in the coagulation process.

\section{Conclusion}

The coagulation method using chitosan can reduce remazol red concentration and the COD value of batik liquid waste. Obtained coagulation optimum $\mathrm{pH}$ conditions $=2$ with a percentage reduction in the dye concentration by $100 \%$. The chitosan coagulant is very good at reducing the concentration of the dye remazol red in acidic conditions, increasing the $\mathrm{pH}$, decreasing the ability of chitosan. The decrease in COD value at the optimum coagulation condition showed a decreased percentage of $71.69 \%$. Further research is needed regarding other parameters that can affect the coagulation process, such as coagulant dose, stirring time, and settling time.

\section{Acknowledgments}

The author would like to thank the Chemical Laboratory of UIN Sunan Kalijaga and the Testing and Calibration Laboratory, Center for Environmental Health Engineering and Disease Control (BBTKLPP), Yogyakarta, for all services and facilities provided.

\section{References}

[1] Rensy Aula Sari, M. Lutfi Firdaus, Rina Elvia, Penentuan Kesetimbangan, Termodinamika dan Kinetika Adsorpsi Arang Aktif Tempurung Kelapa Sawit Pada Zat Warna Reactive Red dan Direct Blue, ALOTROP Jurnal Pendidikan dan Ilmu Kimia, 1, 1, (2017), 10-14

[2] Girda Wahyu Ekowati, Maya Rahmayanti, Kajian Desorpsi Zat Warna Indigosol Blue dari Adsorben Humin Hasil Isolasi Tanah Gambut Riau, Sumatera, Analit: Analytical and Environmental Chemistry, 4, 2, (2019), 68-75

[3] Silvia Riqotul Fuadah, Maya Rahmayanti, AdsorpsiDesorpsi Zat Warna Naftol Blue Black Menggunakan Adsorben Humin Hasil Isolasi Tanah Gambut Riau, Sumatera, Analit: Analytical and Environmental Chemistry, 4, 2, (2019), 59-67

[4] Wachidah Nur Latifah, Maya Rahmayanti, Desorption of Indigosol Blue from Humic Acid Coated $\mathrm{Fe}_{3} \mathrm{O}_{4}$ Particles, Proceeding International Conference on Science and Engineering, Yogyakarta, 2020

[5] Masyithah Nisvi Prandini, Maya Rahmayanti, Effect $\mathrm{pH}$ Adsorption of Naphtol Dye Using Humic Acid Adsorbent Result of Peat Isolation from Kalimantan, Proceeding International Conference on Science and Engineering, 2020

[6] Nunung Faizah Yosi Putri, Maya Rahmayanti, Desorption of Naphtol Blue-Black from Humic Acid Modified Magnetite Using $\mathrm{NaOH}$ as Desorption Agent, Proceeding International Conference on Science and Engineering, 2020

[7] Gita Citra Santi, Maya Rahmayanti, Effect of Solution pH to Indigosol Blue Adsorption on Humic Acid Isolated from Kalimantan Peat Oil, Proceeding International Conference on Science and Engineering, 2019

[8] Imam Syafii, Sintesis Komposit MontmorillonitTiO2 dengan Variasi Suhu Kalsinasi dan Aplikasinya untuk Pengolahan Zat Warna Remazol Red, 
Indonesian Journal of Materials Chemistry, 2, 1, (2019), 10-15

[9] Ign Suharto, Limbah Kimia dalam Pencemaran Udara dan Air, Penerbit Andi, Semarang, 2011

[10] Hendrawati Hendrawati, Delsy Syamsumarsih, Nurhasni Nurhasni, Penggunaan Biji Asam Jawa (Tamarindus indica L.) dan Biji Kecipir (Psophocarpus tetragonolobus L.) Sebagai Koagulan Alami Dalam Perbaikan Kualitas Air Tanah, Jurnal Kimia Valensi, 3, 1, (2013), 23-34

[11] Andika Pradifan, Endro Sutrisno, Mochtar Hadiwidodo, Studi Penggunaan Kitosan Dari Limbah Cangkang Kerang Simping (Amusium Pleuronectes) Sebagai Biokoagulan Untuk Menurunkan Kadar Cod Dan Tss (Studi Kasus: Air Saluran Singosari Semarang), Jurnal Teknik Lingkungan, 5, 3, (2016), 18

[12] Edward J Dompeipen, Isolasi dan identifikasi kitin dan kitosan dari kulit udang Windu (Penaeus monodon) dengan spektroskopi inframerah, Majalah Biam, 13, 1, (2017), 31-41

[13] Shaikat Chandra Dey, Mohammad Al-Amin, Taslim Ur Rashid, Md. Zakir Sultan, Md. Ashaduzzaman, Mithun Sarker, Sayed Md. Shamsuddin, Preparation, characterization and performance evaluation of chitosan as an adsorbent for remazol red, International Journal of Latest Research in Engineering and Technology, 2, 2, (2016), 52-62

[14] Maya Rahmayanti, Erni Yunita, Nunung Faizah Yosi Putri, Study of Adsorption-Desorption on Batik Industrial Dyes (Naphthol Blue Black) on Magnetite Modified Humic Acid (HA-Fe3O4), Jurnal Kimia Sains dan Aplikasi, 23, 7, (2020), 244-248 https://doi.org/10.14710/jksa.23.7.244-248

[15] N. F. El Boraei, M. A. M. Ibrahim, Black binary nickel cobalt oxide nano-powder prepared by cathodic electrodeposition; characterization and its efficient application on removing the Remazol Red textile dye from aqueous solution, Materials Chemistry and Physics, 238, (2019), 121894

https://doi.org/10.1016/j.matchemphys.2019.121894 